\title{
Taking into Account Users' Perceptions in the Design Process: Principles to Create a Digital Design Tool
}

\author{
Renato Fonseca Livramento Da Silva ${ }^{1}$, Angelina Dias Leão Costa ${ }^{1}$, \\ and Guillaume Thomann ${ }^{2(\bowtie)}$ \\ ${ }^{1}$ Universidade Federal da Paraíba, PPGAU, João Pessoa, PB 58033-455, Brazil \\ ${ }^{2}$ Univ. Grenoble Alpes, CNRS, Grenoble INP, G-SCOP, 38000 Grenoble, France \\ guillaume. thomannagrenoble-inp. fr
}

\begin{abstract}
User Centered Design approach is used in many sectors and appropriated by many design teams to defend principles of products adapted to the final users. In the Architectural and Industrial Design disciplines, architects and designers defend principles that could be able to create spaces, public areas or innovated products that are closer as possible as the user behavior. The issue is still the complexity of the user perception and the variability of its interpretation of the environment. The research method used in this research is to combine Universal Design and Usability approaches to be able to extract one first list of principles. The combination of this list with the five human sensorial systems identified in the literature give the structure of a tool that can be proposed to projectists like architects and industrial designers to better consider user perception during the designing process. The result of the research is the proposition of a software coupled with a user friendly interface dedicated to architects and industrial designer. It has the aim to simplify the organization of the early phases of the design process, taking into account designers and architects design priorities and integrating the final user specific sensorial situation.
\end{abstract}

Keywords: Users centered design · Universal design · Usability · Human sensorial system · Digital tool design

\section{Introduction}

Architecture and design give the development of environments, products and services a culturally rooted visually-based bias. In this context, the significant growth of new technologies, especially information-oriented, has exacerbated the predominance of vision as a source of absorption of information available to metropolitan populations. That said, in a way, it is comfortable, from the point of view of the designer, to keep thinking about the project based mainly on visual experience, because culturally the Western world tends to organize itself in this way [1].

This fact reinforces the premise of a material world still largely thought to be visually lived. However, [2] points out that in relation to the challenges of the project in 
today's world, the profusion of dynamically and complexly inserted "codes" in people's daily lives also needs attention, such as the questions related to intangible attributes, aligned with aspects of human behavior, aesthetic and psychological factors. In this sense, according to the author "new creative tools are necessary to fill the gaps that the methodological models used from now are no longer able to answer the current issues" [2].

Studies related to the design process in architecture and design have multiplied considerably in recent years. In particular since the 1960s, the number of proposals for methods, techniques and tools aimed at contributing to the control and organization of the design process has increased considerably, mainly due to the technological increasing complexity of products [3-5].

However, in recent decades, discussions in the design field have paid particular attention to User Centered Design (UCD), which focuses more on taking into account behavioral, social, physical and cognitive aspects of the users [6]. It is based on the effective participation of users throughout the whole project, in order to collect information on their experiences for solutions closer to their needs [7, 8]. In this context, Universal Design (UD) and Usability contribute significantly to the UCD process, while presenting similarities in their criteria: DU aimed to establish wide access to products and Usability focused on the ease of use [9].

Due to previous observations, there is currently no tool that can help the industrial designer or the architect to take in consideration a variety of human perceptions of an environmental space occupation.

Objectives of the current research are focused on:

- From architects and industrial designers points of view, assessing the need for a tool to help the structure of ideas in the early phases of the design process,

- How Design Universal, Usability and the Human Sensorial System can contribute to such a process?

- Finally, is it possible to structure a tool to assist architects and industrial designers during these initial steps of the process?

\section{Methods}

The research method is organized in two steps.

First of all the different fields of the literature review give some orientation of the research. Thanks to the evolution of the history of the architecture domain, it is clear that the UCD approach has to be included into the current study. UCD is an approach in which user characteristics, usability goals, environment, tasks and workflow of a product, service or process are given extensive attention at each stage of the design process. In the context of designing an environmental space, the usability of this space has to be study. Moreover, this space should ideally suit any individual. Universal Design (UD) is the design of any layout, product, equipment, program or service that can be used by any person, without requiring any adaptation or special design, regardless of gender, age, location or his handicap. To be sure not to be limited to the visual perception of the user, all the human sensory perception system has to be taken into account during this study. 
Secondly, data collection was carried out in two steps to better fix the requirements of specialists and being able to develop a first version of a tool. The first one took place through a questionnaire with 13 Brazilian students from the Architecture and Urbanism Post-Graduate Program in one Brazilian Federal University. All of them were regularly enrolled in the subject. The students had a degree in architecture, engineering and economics, with 4 men and 9 women between 25 and 43 years old. Questionnaire was structured in three parts: (1) participants characteristics, (2) knowledge about creativity and creativity tools and (3) personal experience related to UD, Usability and sensoryhuman systems.

In the second one, students' groups follow-up was carried out at a French university. 20 students divided into four groups during the development of creative design steps (common project) were observed. Students were between the ages of 18 and 27, with 13 women and $7 \mathrm{men}$; all of them have some experience in product design and/or environments. The teams were composed of students of architecture, design and product engineering of different French universities and of different periods in their respective courses. The aim of this study was (1) to explore the design methodologies known by all the members before the realization of the project and (2) how they combine and decide the use of one unique methodology during the project (steps and tool used in relation to UD, Usability and sensory-human systems).

Finally, a first version of a tool structure was proposed and a first prototype of software was developed. It has to be evaluated.

\section{Results}

\subsection{Contributions from Literature}

Universal design is known as a global design trend and has a broad and diverse scope [10]. However, its principles are relatively difficult to apply because there are few clearly defined methods for this [11]. On the other hand, [12] declares that "the theme of usercentered design is directly linked to usability", a factor which makes us deduce a strong overlap between the two themes.

Table 1. Principles of usability [13] and UD [14]

\begin{tabular}{l|l|l}
\hline Usability & Universal design & New denomination \\
\hline Consistency, compatibility, evidence & Simple and intuitive use & Compatibility \\
\hline Feedback, error prevention & Fault tolerance & Warning \\
\hline Visual clarity, prioritization of functionality and information & Perceptible information & Communication \\
\hline Transfer of technology & & Materialization \\
\hline Capacity, user control & Flexibility of use and equitable use & Adaptability \\
\cline { 2 - 3 } & Minimum physical effort & Force \\
\cline { 2 - 3 } & Space dimensioning & Dimensioning \\
\hline
\end{tabular}

The two first column of the following table (Table 1) come from the literature. They consist of the lists of the 7 principles of the Universal Design and the 10 principles of the 
Usability. The last column is a proposition of reduction of variables with the perspective of using them inside the future proposed tool.

To be able to not only consider the human visual system in the research proposal, the use of the information acquisition given in [15] is chosen. Five sensorial systems are established: Basic Guidance System, Haptic System, Visual System, Auditory System and the Smell System/Taste. Such information can be obtained with any of the perceptual systems alone, or by any combination of them.

\subsection{Requirements List}

This requirements list was established from the two steps realized with groups of students in France and Brazil. Analysis of the answers of the questionnaires gave a certain number of functions that the future tool has to realize. Categories of requirements where proposed to better structure the result of the analysis (Table 2).

Table 2. Requirements list established from the questionnaires

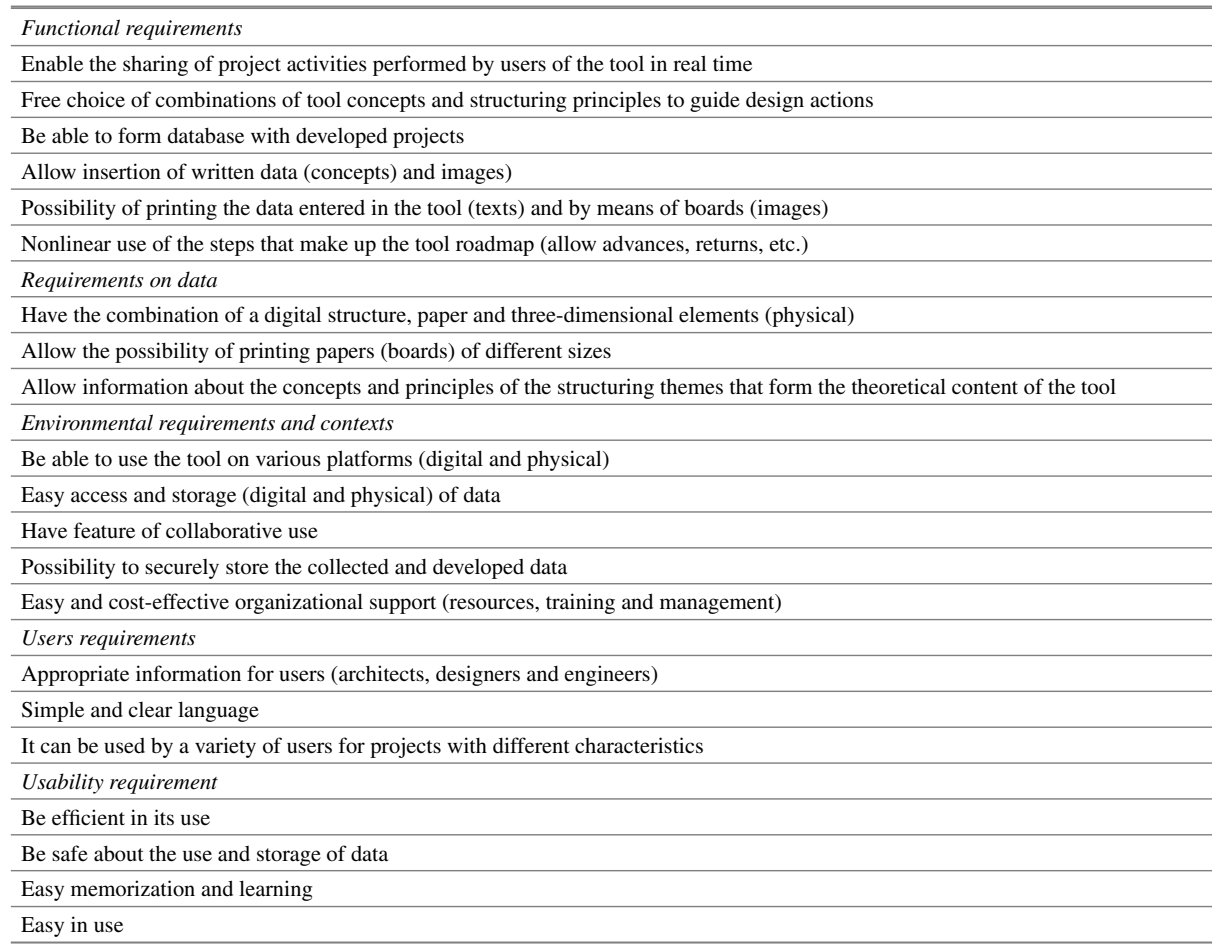

\subsection{Digital Tool User Interface}

The web oriented tool consists of a software that allow the architect (for example) to better manage its projects centered to the human use of the environment. After the 
creation of the project, the user friendly interface shown in Fig. 1 oblige the architect to select all combinations of principles before closing it. Thus, he has to think about solutions/proposals for each of them during the creativity phase of the project. Logically, he select the most adapted combinations of principles at first (depending of the project characteristics) ... knowing that sometime, new solutions come from others points of view. He can add illustrations, comments, schemas etc. and then print the document to constitute the archives of the complete project.

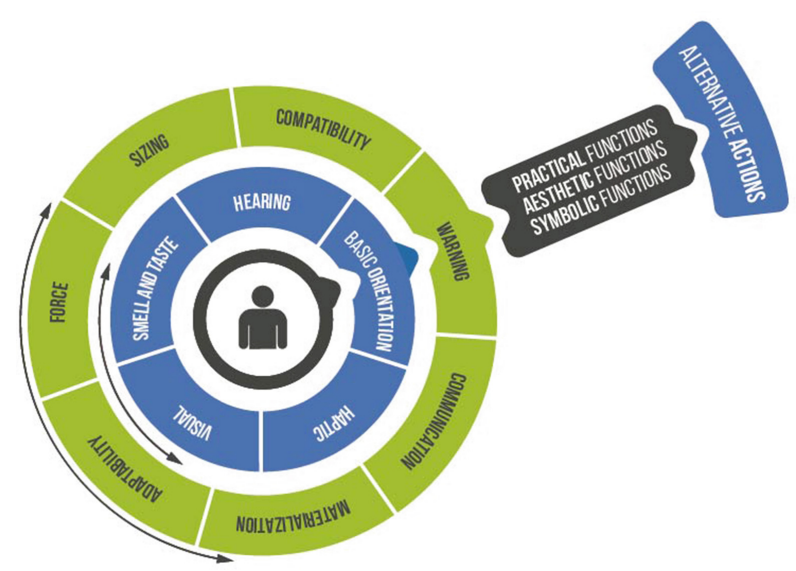

Fig. 1. Image of the dynamic user-friendly human interface the project manager has to manipulate to select a combination. For each combination (one blue principle with one green principle), he can propose one or more architectural solution to be used for the final proposal [16].

\section{Conclusion and Perspectives}

Design processes used by architects and industrial designers are complex and need frequent adaptation with the context of use in the future working environment. Products or working spaces have to be dedicated to all the characteristics of the final users. Theoretical approaches exist to follow and support these needs. The software proposed is based on 7 Universal Design and Usability principles and is complete by 5 human sensorial systems. The combination give 35 couples of principles that the architect or industrial design has to use to propose final solution.

\section{References}

1. Herssens, J.: Designing architecture for more: a framework of haptic design parameters with the experience of people born blind. Hasselt: University Hasselt (2011)

2. De Moraes, D.: Metaprojeto: o design do design. Blucher, São Paulo (2010)

3. Di Russo, S.: Understanding the behaviour of design thinking in complex environments. Thesis (for the degree of Doctor of Philosophy) - Swinburne University of Technology, Melbourne (2016) 
4. Van Der Linden, J.C.d.S., Lacerda, A.P.: Metodologia projetual em tempos de complexidade. In: Martins, R.F.d., Van Der Linden, J.C.d.S. (org.). Pelos caminhos do design: metodologia de projeto. Londrina: Eduel, pp. 83-149 (2012)

5. Cross, N.: A history of design methodology. In: Vries, M.J.d., Cross, N., Grant, D.P. (eds.) Design Methodology and Relationships with Science, pp. 15-27. Kluwer Academic Publishers, Dordrecht (1993)

6. Fletcher, V., Crolius, W.A., Harada, F.J.B.: Improving senior ridership on public transit: an approach to working with user/experts to review the public transportation for the city of Cambridge/MA with emphasis on universal design. In: 2015 Universal Design Symposium. NC State College of Design (2015)

7. Tschimmel, K.C.: Design as a perception-in-action process. In: Taura, T., Nagai, Y. (eds.) Design Creativity 2012 (ICDC). Springer, London (2012)

8. Norman, D.A.: Human-centered design considered harmful. Interactions 12(4), 14-19 (2005)

9. IIDA, Itiro; GUIMARÃES, Lia Buarque de Macedo. Ergonomia: projeto e produção. 3 ed. revista. Blucher, São Paulo (SP) (2016)

10. Lin, K.-C., Wu, C.-F.: Practicing universal design to actual hand tool design process. Appl. Ergon. 50, 8-18 (2015)

11. Boisadan, A. : Conception universelle pour une signalétique intuitive et accessible à tous. Thèse de doctorat en Ergonomie, École doctorale 261 «Cognition, Comportements, Conduites Humaines» Laboratoire Adaptations, Travail, Individu. Université Paris Descartes. Paris (2018)

12. Merino, G.S.A.D.: Metodologia para a prática projetual do designcom base no projeto centrado no usuário e com ênfase no design universal. Tese (Doutorado em Engenharia de Produção) - Universidade Federal de Santa Catarina, Florianópolis (2014)

13. Jordan, P.: An Introduction to Usability. Taylor \& Francis, London (1998). 120 p.

14. CUD: The Center for Universal Design. Universal Design: product evaluation countdown. Raleigh, North Carolina State University (2002)

15. Gibson, J.J.: The Senses Considered as Perceptual Systems. Houghtan Miffin, Boston (1966)

16. Fonseca Livramento Da Silva, R., Dias Leão Costa, A., Thomann, G.: Design tool based on sensory perception, usability and universal design. In: 29th CIRP Design 2019, Póvoa de Varzim, Portugal (2019)

Open Access This chapter is licensed under the terms of the Creative Commons Attribution 4.0 International License (http://creativecommons.org/licenses/by/4.0/), which permits use, sharing, adaptation, distribution and reproduction in any medium or format, as long as you give appropriate credit to the original author(s) and the source, provide a link to the Creative Commons license and indicate if changes were made.

The images or other third party material in this chapter are included in the chapter's Creative Commons license, unless indicated otherwise in a credit line to the material. If material is not included in the chapter's Creative Commons license and your intended use is not permitted by statutory regulation or exceeds the permitted use, you will need to obtain permission directly from the copyright holder.

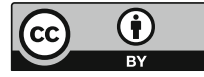

